\section{Food habits of the Leopard Panthera pardus in Dachigam National Park, Kashmir, India}

\section{G. Mustafa Shah ${ }^{1}$, Ulfat Jan ${ }^{1}$, Bilal A. Bhat ${ }^{2}$, Fayaz Ahmad $^{1}$ \& Javid Ahmad ${ }^{1}$}

1,2 P.G. Department of Zoology, University of Kashmir, Srinagar Jammu \& Kashmir 190006, India

Email: ${ }^{2}$ bilalwildlife @yahoo.co.in (corresponding author)

It is known that the Leopard (Panthera pardus) feeds on a range of mammalian species, but studies of leopard food habits are hampered by the animals' secretive and nocturnal habits. In Dachigam National Park this challenge is made even more difficult by thick forests, which preclude direct observation of leopard behaviour. This study was undertaken to provide information on the food preferences of leopard in Dachigam National Park via scat analysis.

\section{Study Area}

Dachigam National Park, $\left(34^{\circ} 05^{\prime}-34^{\circ} 12^{\prime} \mathrm{N} \& 74^{\circ} 54^{\prime}-\right.$ $75^{\circ} \mathrm{O} 9^{\prime} \mathrm{E}$ ) is situated $21 \mathrm{~km}$ northeast of Srinagar (Fig. 1). Roughly rectangular, the park has a total area of $141 \mathrm{~km}^{2}$. It is approximately $24 \mathrm{~km}$ in length and $6 \mathrm{~km}$ in breadth ranging in altitude from $1700 \mathrm{~m}$ to $4000 \mathrm{~m}$. A more or less continuous range of mountains borders the national park except in the west, where it has been artificially fenced. The average climate of Dachigam is sub-Mediterranean. The park is generally divided into lower $\left(26 \mathrm{~km}^{2}\right)$ and upper Dachigam $\left(115 \mathrm{~km}^{2}\right)$ by the beginning of fir forest.

\section{Materials and Methods}

Analysis of leopard scats was carried out to estimate the proportion of different prey species consumed in a nondestructive, cost and time effective manner (Schaller 1967

Date of publication 26 March 2009

ISSN 0974-7907 (online) | 0974-7893 (print)

Editor: L.A.K. Singh

Manuscript details:

Ms \# 01833

Received 08 August 2007

Final received 13 December 2007

Finally accepted 03 November 2008

Citation: Shah, G.M., U. Jan, B.A. Bhat, F. Ahmad \& J. Ahmad (2009). Food habits of the Leopard Panthera pardus in Dachigam National Park, Kashmir, India. Journal of Threatened Taxa 1(3): 184-185.

Copyright: ( ) G. Mustafa Shah, Ulfat Jan, Bilal A. Bhat, Fayaz Ahmad \& Javid Ahmad 2009. Creative Commons Attribution 3.0 Unported License. JoTT allows unrestricted use of this article in any medium for non-profit purposes, reproduction and distribution by providing adequate credit to the authors and the source of publication.

Acknowledgement: We thank the Wildlife Department for permission and support to carry out the field work; and to the Department of Science and Technology, Govt. of India for providing financial assistance under the research project entitled "Bio-ecology of Hangul Deer, Cervus elaphus hanglu and its relationship with the predators at Dachigam National Park, Kashmir".

OPEN AGCESS | FREE DOWNLOAD
Sunquist 1981; Johnsingh 1983; Karanth \& Sunquist 1995). Leopard scats were collected by walking regular transects in the field. Eight transects in lower Dachigam (24.5 km in length) and six in higher Dachigam (54km in length) were covered in a manner that included all the habitat types found in the park. Scats were identified based on associated signs and tracks, size and appearance. The scats collected were washed and the remains such as hair, bones, hooves, claws, nails, teeth, feathers etc. were separated for species identification (Koppikar \& Sabnis 1976, 1979; Mukherjee et al. 1994a,b; Sunquist 1995; Karanth \& Sunquist 1995; Biswas \& Sankar 2002)

The hairs of prey species were sampled following Mukherjee et al. (1994a) and compared with reference slides in the laboratory collection of the Wildlife Institute of India, Dehradun, India. Identification was based on the general appearance of the hair, colour, length, medullary structure and cuticular pattern (Moore et al. 1974; Mukherjee et al. 1994b). Quantification of the diet was based on both frequency of occurrence expressed as percentage (Proportion of total scats in which an item was found) and percent occurrence (number of times a specific item was found as a percentage of all items found) (Ackerman et al. 1984).

\section{Results and Discussion}

The result of leopard scat analysis is summarized in Table 1. The analysis of 96 leopard scats revealed the presence of nine prey species. The principal prey items were dog, langur, hangul and rodents with a percentage occurrence of $21.0,21.0,18.4$ and 15.7 respectively. Henschel et al. (2005) reported that leopards preyed mainly on ungulates, primates and rodents. Karanth \& Sunquist (1995) reported that leopard fed on different prey species like langur, chital, chevrotain, porcupine etc. The surrounding villages of Dachigam National Park contain a sizeable dog population providing easy targets for leopards. Johnsingh (1983) identified chital, sambar, cattle, langur and hare as leopard prey from scats, and reported killing of village dogs by leopard in Bandipur. Aside from the lone bird remains found in one of the scats, the leopard diet was entirely composed of mammal species in Dachigam National Park. Rice (1986) observed that the diet of leopard in Eravikulam National Park, Kerala consisted mainly of Sambar (Rusa unicolor) and Nilgiri Tahr (Nilgiritragus hylocrius). The percent occurrence of cattle, sheep and goat put together was significant $(18.3 \%)$ in the diet of leopard in Dachigam National Park during summer and autumn months. It was related to the presence of heavy cattle stocks during these months in Dachigam that were easily accessible prey for the leopard. Johnson et al. (1993) reported that large- and medium-sized mammals composed the majority of the leopard diet, with livestock, pheasants, grass and soil eaten occasionally. These dietary shifts may reflect opportunistic encounters leading to changes in leopard hunting behaviour, prey availability or prey vulnerability. Karanth \& Sunquist (2000) related predator activity to that of the prey species. During winter and early spring the scats were mostly found to contain hangul and langur hairs. This may be due to the fact that during winter because of heavy snow cover hangul deer and langur remain concentrated in a small belt of lower Dachigam and could become easy targets of leopard. Some prey species tend to 
Table 1. Prey of the Leopard Panthera pardus in Dachigam National Park

\begin{tabular}{llll}
\hline Species & $\begin{array}{l}\text { No. of scats } \\
\text { containing the } \\
\text { prey item }(\mathbf{n}=96)\end{array}$ & $\begin{array}{l}\text { Frequency of } \\
\text { occurrence } \\
\text { expressed as } \\
\text { percentage }\end{array}$ & $\begin{array}{l}\text { Percentage } \\
\text { occurrence }\end{array}$ \\
\hline Dog & 24 & 25 & 21 \\
Langur & 24 & 25 & 21 \\
Hangul & 21 & 21.8 & 18.4 \\
Rodent & 18 & 18.7 & 15.7 \\
Sheep & 8 & 8.3 & 7 \\
Goat & 6 & 6.2 & 5.2 \\
Cattle & 7 & 7.2 & 6.1 \\
Serow & 1 & 1 & 0.8 \\
Birds & 1 & 1 & 0.8 \\
Unknown & 4 & 4.1 & 3.5 \\
\hline
\end{tabular}

congregate in small areas in deeper snow as forage becomes unavailable elsewhere (Fuller 1991) and encounter rates may increase (Huggard 1993). Among mammal species, serow was least represented in the diet with the percentage occurrence of 0.8 .

Anecdotal reports from across the country suggest that dogs form one of the major prey of leopards in human-dominated landscapes.

\section{References}

Ackerman, B.B., F.G. Lindzey \& T.P. Hernker (1984). Cougar food habits in southern Utah. Journal of Wildlife Management 48: 147155 .

Biswas, S. \& K. Sankar (2002). Prey abundance and food habit of tigers (Panthera tigris tigris) in Pench National Park, Madhya Pradesh, India. Journal of Zoology 256: 411-420.

Fuller, T.K. (1991). Effect of snow depth on wolf activity and prey selection in north central Minnesota. Canadian Journal of Zoology 69: 283-287.

Henschel, P., K.A. Albernetty \& L.J.T. White (2005). Leopard food habits in the Lope National Park, Gabon, Central Africa. African Journal of Ecology (1): 21-28(8).

Huggard, D.J. (1993). Effect of snow depth on predation and scavenging by Gray wolves. Journal of Wildlife Management 57(2): 382-388.

Johnsingh, A.J.T. (1983). Large mammalion prey-predator in Bandipur. Journal of the Bombay Natural History Society 80: 1-57.

Johnson, K.G., W. Wei, D.G. Reid \& H. Jinchu (1993). Food Habits of Asiatic Leopards (Panthera pardus fusea) in Wolong Reserve, Sichuan, China. Journal of Mammalogy 74(3): 646-650.

Karanth, K.U. \& M.E. Sunquist (2000). Behavioural correlates of predation by tiger (Panthera tigris) Leopard (Panthera pardus) and dhole (Cuon alpinus) in Nagarahole, India. Journal of Zoology 250: 255-265.

Karanth, K.U. \& M.E. Sunquist (1995). Prey selection by tiger, Leopard and dhole in tropical forests. Journal of Animal Ecology 64: 439-450.

Koppikar, B.R. \& J.H. Sabnis (1976). Identification of hairs of some Indian Mammals. Journal of the Bombay Natural History Society 73: 520.

Koppikar, B.R. \& J.H. Sabnis (1979). Aids to the identification of artiodactylan hairs with general comments on hair structure. Journal of the Bombay Natural History Society 78: 299-302.

Mukherjee, S., S.P. Goyal \& R. Chellam (1994a). Refined techniques for the analysis of Asiatic Lion Panthera leo persica scats. Acta Theriologica 39: 425-430.

Mukherjee, S., S.P. Goyal \& R. Chellam (1994b). Standardization of scat analysis techniques for Leopard (Panthera pardus) in Gir National Park, western India. Mammalia 58: 139-143.

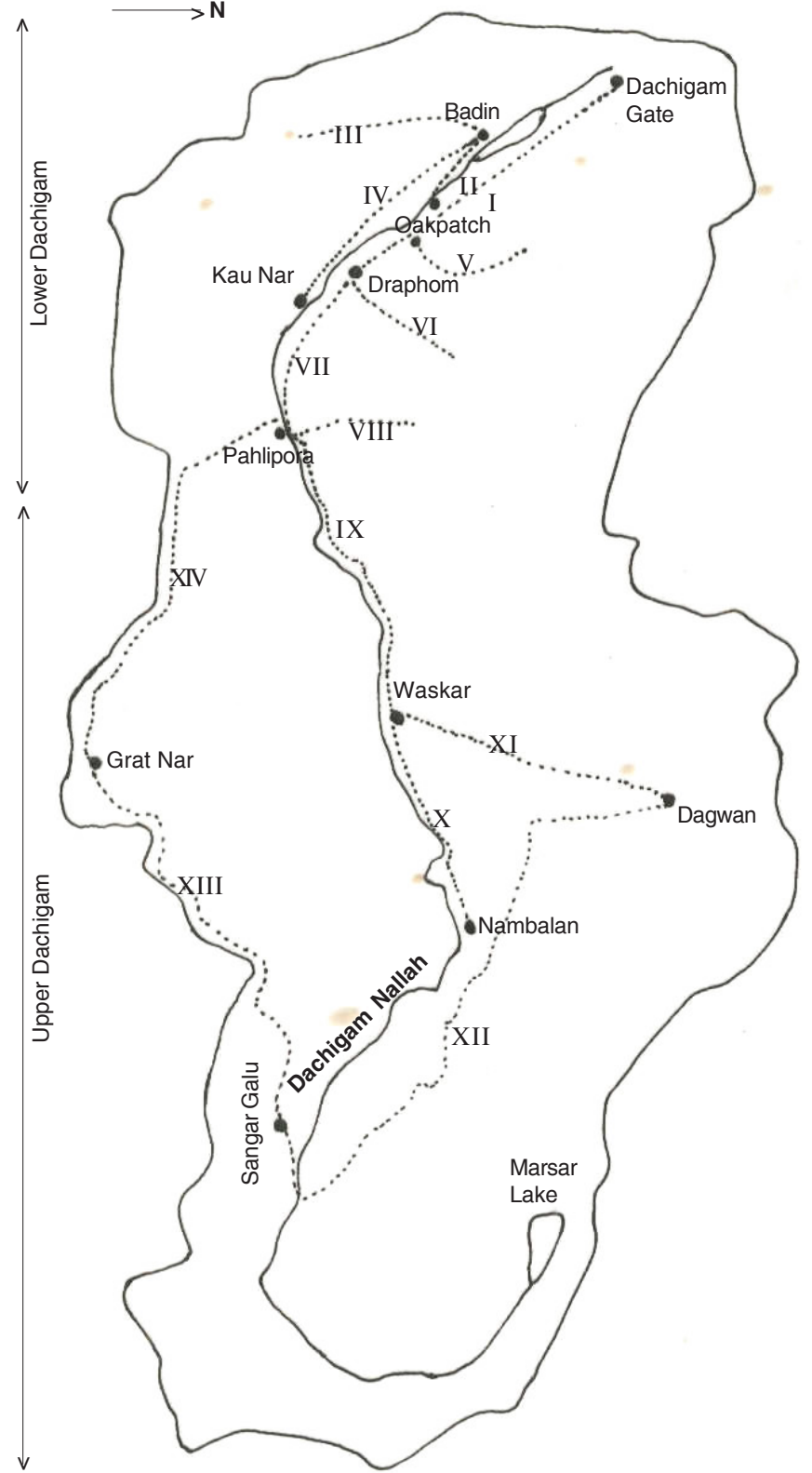

Figure 1. Dachigam National Park (Scats collected along transects I-XIV).

Rice, C.G. (1986). Observation on Predators and Prey at Eravikulam National Park, Kerala. Journal of the Bombay Natural History Society 83: 283-305.

Schaller, G.B. (1967). The Deer and the Tiger: A Study of Wildlife in India. University of Chicago Press, Chicago, $361 \mathrm{pp}$.

Singh, G. \& P. Kachroo (1976). Forest Flora of Srinagar. Bishen Singh Mahandrapal Singh: Dehradun, 278pp.

Sunquist, M.E. (1981). The social organization of tigers (Panthera tigris) in Royal Chitwan National Park Smithson. Contributions to Zoology 336: $1-98$, 